\title{
PRICE TRANSMISSION IN SELECTED MALAYSIAN FRUITS MARKETS
}

\author{
Fatimah Mohamed Arshad and Amna Awad Abdel Hameed \\ Institute of Agricultural and Food Policy Studies, Faculty of Economics and Management, \\ Putra Infoport, University Putra Malaysia, 43400 Serdang Selangor, Malaysia
}

Received 2012-08-04; Revised 2013-08-23; Accepted 2013-12-28

\begin{abstract}
The market for fresh produce such as fruits in Malaysia is alleged to be inefficient due to poor flow of information between market levels and uncompetitive market particularly at the wholesale and retail levels. Due to these structural problems, pricing efficiency is questionable, in that they are not integrated. This study intends to examine the cointegration and causality relationships between the farm and retail prices in the Malaysian market of fruits. To that end, the bivariate cointegration approach, using Granger causality tests, is applied. The study uses monthly data from January 2000 through December 2010. The results show that there is evidence of long run bidirectional causal relationship between farm and retail prices for banana and watermelon. However, the analysis revealed a long run unidirectional relationship from farm prices to retail prices with no evidence of reverse or feedback causality running from farm price to retail prices for jackfruit and durian.
\end{abstract}

Keywords: Causality Tests, Cointegration, Farm Prices, Retail Prices

\section{INTRODUCTION}

The process of price movements transmission taking place all through upstream phases to the ultimate consumer, in the food sector, has been one of the most investigated areas in the agricultural economics literature for policy objectives (Palaskas, 1995). Given that price is the primary mechanism by which various levels of the market are linked, the extent of adjustment and speed with which shocks are transmitted between different price levels, is a significant factor showing the actions of participants at various market levels and provides some implications on market integration. Non-integrated markets may give imprecise depiction about price information, which might distort production decisions and lead to inefficiencies in markets, harm the final consumer and bring about low production and retard growth, specifically in rural economy.

Agricultural economists have focused on the farmto-retail price transmission process because the relationship between farm and retail prices provides insights into marketing efficiency and consumer and farmer welfare. The analysis of price relations along the value chains of agricultural products has recently benefited from the progress of time series econometrics. Structural shocks on the market of raw materials are supposed to affect the final consumers (Bakucs and Ferto, 2006). In particular, long run price transmission can be extended to evaluate patterns of Granger causality and dynamic features as in Goodwin et al. (1996). Food retail prices and farm prices may drift apart in the short run due to policy changes or seasonal factors, but if they continue to be too far apart, economic forces, such as market mechanisms may bring them together, in the long run (Palaskas, 1995; Enders and Siklos, 1998). As markets become more integrated, it is expected that each market employs information from the others when forming its own price expectations and therefore bidirectional causality should be present. Likewise, more integration will be accompanied with a greater interdependence among prices in the short run, such that every price contributes to explain the evolution of the others. Corresponding Author: Fatimah Mohamed Arshad, Institute of Agricultural and Food Policy Studies, Faculty of Economics and
Management, Putra Infoport, University Putra Malaysia, 43400 Serdang Selangor, Malaysia Fax: 6038943
2611, Tel: 60389471070 


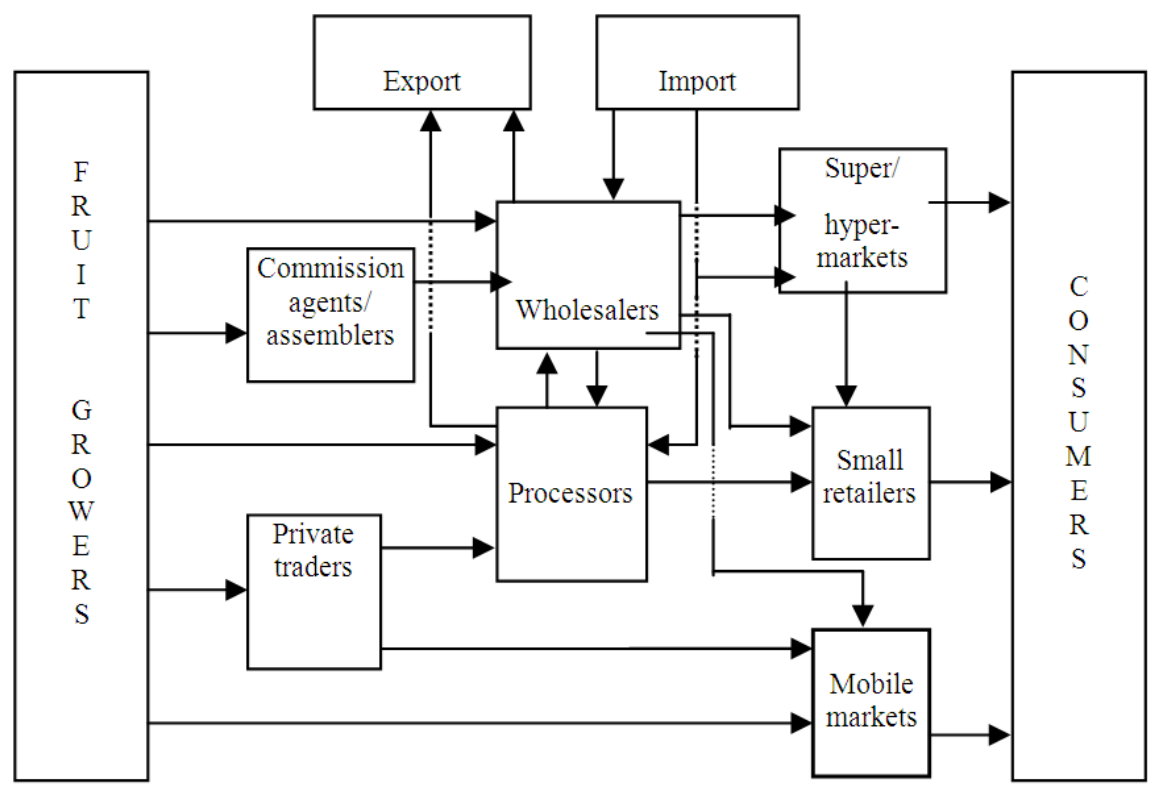

Fig. 1. Marketing Channel of Fruits in Malaysia Source: Arshad et al. (2005a)

Dawson and Tiffin (2000) identify a long run price relationship between UK lamb farm-retail prices and study the seasonal and structural break properties of the series, concluding that the direction of Granger (1969) causality is from the retail to producer prices; thus, lamb prices are set in the retail market. Goodwin and Holt (1999) find that farm markets do adjust to wholesale market shocks, whilst the effect of the retail market shocks are largely confined to retail markets. Goodwin and Harper (2000) in their pork market study find a unidirectional price information flow from farm to wholesale and retail levels. Bakucs and Ferto (2006) reported that most empirical results emphasise the presence of feedback between the different market levels and they establish a mostly unidirectional price information flow from farm to wholesale and finally retail levels. However, they mentioned that these studies often yield contradictory results because they were conducted using very different statistical methods, data and various underlying assumptions, getting valid conclusions about the general outcome of price transmission studies is rather difficult. Colclough and Lange (1982) claimed that there are theoretical reasons to expect causality to run also from consumer prices to producer prices. Furthermore, they performed Granger and Sims tests and concluded that in fact causality runs in the opposite direction or might be bidirectional.
Price analysis of the local fruits provides an insight to the behaviour of prices over time and between different levels of the market. This study contributes to the existing literature on fruit price analysis by adding the first systematic quantitative analysis of the relationship between farm and retail prices of fruits in Malaysia, through the application of a recent cointegration methodology for investigating long run relationships. It uses Granger tests for causality relations between the variables, considering their time series properties, to obtain the general pattern of influences to study the transmission of farm price changes to changes in retail prices in the Malaysian fruit market, over sample period.

The remainder of the study is organized as follows: Section II briefly describes the market channel of fruits in Malaysia. Section III outlines the empirical methodology and Section IV reports and discusses the results while a summary and some conclusions are presented in Section V.

\subsection{Marketing Channel of Fruits in Malaysia}

The marketing channel of the local fruits in Malaysia is illustrated in Fig. 1. As shown in the figure, at the farm level the farmers can either sell directly to the traders, wholesaler or through their agents or assemblers. The assemblers are normally transporters who are working for the wholesalers. There are also farmers who sell direct to the processors or the private traders. The farmers could sell either directly to the consumers or 
through private traders in the "mobile" markets. There are two types of "mobile" markets in the country. The first is the "Farmers' Market" (Pasar Tani), which is a mobile market organized and administered by Federal Agricultural Marketing Authority (FAMA) to give the farmers outlets for selling their agricultural produce to consumers. The other is the moving markets managed by the town municipalities.

The retail sector can be divided into three subsectors: Super/hypermarkets, the small retailers and "mobile" markets. Fruits and vegetables are primarily sold through "wet" retail markets but about $20 \%$ of them are distributed through the "dry" retail market hyper/supermarkets. A small number of farmers are involved in contract marketing with processors who sell processed products (juices and canned fruits) to local wholesalers, hypermarkets, retailers and importers. The emergence of hypermarkets largely owned by the MNCs in the 1990s has been a significant development in the retail sector. In 2009, there were 154 foreign-owned retail stores operating in the country (KPDNHEP is Kementerian Perdagangan Dalam Negeri dan Hal Ehwal Pengguna or Ministry of Domestic Trade and Consumer Affairs). One of the major characteristics of the fruits market is the lack of competition among wholesaler and growing concentration of the large scale retailers. For instance, the concentration ratio of top four large scale retailers was estimated at $33 \%$ in 2011 which suggest their stronghold over the market.

The farm level is characterised by a large number of small and fragmented farms. For instance, there were 270,000 growers working on 257,000 hectares of land planted with fruits in 1998 (Arshad et al., 2005b). Out of this total hectarage, only 86,000 ha or $33.4 \%$ are considered commercial farms and the average farm size is 0.67 ha. Agricultural produce are generally unstable in production and inconsistent in quality and quantity. With the exception of small percentage of commercialised farms, majority of small farmers are dependence on the wholesalers for financial loans and agricultural inputs to sustain their livelihood which leads to a strong unidirectional symbiotic relationship between the producers and their buyers. With the growing concentration of the retail chains as compared to the large number of small farms, it would be interesting to see the causality link and extent of price integration between the market levels.

\section{MATERIALS AND METHODS}

As mentioned previously, the objective of this study is to investigate the possible causality links between farm and retail prices in the Malaysian fruits market. The study adopts a simple model to express the relationship between farm and retail prices for selected fruits and test the hypothesis of whether changes in farm prices play an important role in changing retail prices for fruits in Malaysia Equation (1):

$\operatorname{lnRP} P_{\text {it }}=\alpha_{0}^{\prime}+\alpha_{1}^{\prime} \operatorname{lnFP} P_{\text {it }}+v_{t}^{\prime}$

where, $\alpha_{0}^{\prime}$ is constant term, $\mathrm{RP}_{\mathrm{it}}$ and $\mathrm{FP}_{\mathrm{it}}$ are the retail and farm prices, respectively, for the i's fruit type at time $t$ and $\mathrm{v}_{\mathrm{t}}{ }_{\mathrm{T}}$ is the error term.

To investigate whether or not a stable linear steadystate relationship exists between the variables under study, we need to conduct unit-root and cointegration tests for them. Unit-root tests show if a time-series variable is stationary. This study applies the Augmented Dicky-Fuller (ADF) tests to decide the order of integration of the series of the two variables. The (ADF) test was proposed by Dickey and Fuller (1981) as an enhancement of the original Dicky-Fuller test (DF) (1979). A drawback of the original (DF) is that it does not take into account possible autocorrelation in the error process, $\varepsilon_{\mathrm{t.}}$.

The ADF test is given by Equation (2):

$\Delta \mathrm{y}_{\mathrm{t}}=\beta_{0}+(1-\rho) \beta_{1} \mathrm{~T}-\rho \mathrm{y}_{\mathrm{t}-1}+\sum_{\mathrm{i}=1}^{\rho} \gamma_{\mathrm{i}} \Delta \mathrm{y}_{\mathrm{t}-\mathrm{i}}+\varepsilon_{\mathrm{t}}$

where $y_{t}$ is the time series of interest, $T$ is a linear deterministic time trend, $\mathrm{p}$ is the order of augmentation of the test and $\varepsilon_{\mathrm{t}}$ is a white noise error term. The pth order ADF test statistics is given by the t-statistics of $\rho$. There are four possibilities: First, $\mathrm{y}_{\mathrm{t}}$ is stationary with no time trend $\left(\beta_{1}=0, \rho \neq 0\right)$; second, $y_{t}$ is stationary with a time trend i.e., trend stationary $\left(\beta_{1} \neq 0, \rho \neq 0\right)$; third, $\mathrm{y}_{\mathrm{t}}$ is nonstationary with no time trend $\left(\beta_{1}=0, \rho=0\right)$; finally, yt is non-stationary with a time trend $\left(\beta_{1} \neq 0, \rho\right.$ $=0)$ (Romilly et al., 2001). If the variables considered are non-stationary and integrated of order one (i.e., I(1)), then the possibility of a cointegrating relationship between them becomes likely. According to Engle and Granger (1987), two I(1) series are said to be cointegrated if there exists some linear combination of the two which produces a stationary trend $(\mathrm{I}(0))$. In other words, cointegrated series are related over time. Any non-stationary series that are co integrated may diverge in the short run, but they must be linked together in the long run. Therefore, co integration suggests that there must be Granger casualties in at least one direction i.e., 
at least one of the variables may be used to forecast the other. Moreover, it has been proven by Engle and Granger (1987) that if a set of series are co integrated, there always exists a generating mechanism, called "error-correction model", that restricts the long run behaviour of the endogenous variables to converge to their counterbracing relationships, while allowing a wide range of short-run dynamics.

Thus, the second step of this investigation is to test out for the existence (or absence) of cointegration. Here, the Johansen (1991) test, which has the advantage that both estimation and hypothesis testing are performed in a unified framework, is utilized. The Johansen approach has been extensively documented so we will only briefly describe the setup and testing procedure. For further detailed discussion readers are referred to (Johansen, 1988; Johansen and Juselius, 1990). Johansen (1988) uses the Vector Error Correction Model (VECM) as a starting step for estimation. From a Vector Autoregression (VAR) of order $p$ the $k \times 1$ vector of $\mathrm{I}(1)$ variables $\mathrm{Y}_{\mathrm{t}}$ can be defined as Equation (3):

$\mathrm{Y}_{\mathrm{t}}=\mu+\sum_{\mathrm{i}=1}^{\mathrm{p}} \mathrm{A}_{\mathrm{j}} \mathrm{Y}_{\mathrm{t}-\mathrm{i}}+\varepsilon_{\mathrm{t}}$

where, $\varepsilon_{\mathrm{t}}$ is an i.i.d. error term. The VAR model (3) can be parameterized in a Vector Error Correction Model (VECM) form can be found by solving the change in $\mathrm{Y}_{\mathrm{t}}$ as follows Equation (4):

$\Delta \mathrm{Y}_{\mathrm{t}}=\mu+\sum_{\mathrm{i}=1}^{\mathrm{p}-1} \Gamma_{\mathrm{i}} \Delta \mathrm{Y}_{\mathrm{t}-\mathrm{i}}-\Pi \mathrm{Y}_{\mathrm{t}-1}+\varepsilon_{\mathrm{t}}$

where, $\Gamma_{j}=-\sum_{j=i+11}^{p} A_{i}-I, \quad \Pi=\sum_{i=1}^{p} A_{i}-I$

The long run information is found in the $\Pi$ matrix and the rank of this matrix determines the number of cointegrating relationships. If the rank of $\Pi$ equals $p$ (the size of the Yt matrix) then Yt themselves are stationary. If the rank is less than $\mathrm{p}$ but greater than zero then some independent unit roots exist. If $p$ equals zero, then all unit roots are independent. If the rank $r$ is $0<r<p$ then $\Pi$ can be decomposed using a reduced rank regression into $\Pi=\alpha \beta$ '. Because the rank of $\Pi$ is usually unknown, Johansen proceeds to develop test procedures (The Trace and The maximum eigenvalue test statistics) to test the rank of $\Pi$. The tests are based on the eigenvalue solution to the reduced rank regression:

$$
\text { Trace statistics }=-\mathrm{T} \sum_{\mathrm{i}=\mathrm{q}+1}^{\mathrm{N}} \ln \left(1-\hat{\lambda}_{\mathrm{i}}\right)
$$

where, $\hat{\lambda}_{\mathrm{i}}$ is the estimated eigenvalue and $\mathrm{q}$ is the null hypothesis that at most q cointegrating vectors exist. The alternative hypothesis is that at least one more cointegrating vector than the null exists (i.e., $r>q$ ).

The maximum eigenvalue that tests the null hypothesis of $q$ cointegrating relations against the alternative of $q+1$ cointegrating relations can be computed as:

The maximum eigenvalue statistics $=-\operatorname{Tl}\left(1-\bar{\lambda}_{q+1}\right)$

For $\mathrm{q}=0,1, \ldots, \mathrm{k}-1$.

The final step of our investigation is to examine the underlying causal relationship between the two variables within a bivariate framework. We employ the Granger (1969; 1980) causality test because of its favourable finite sample properties as reported in Guilkey and Salemi (1982) and Geweke et al. (1983). In the bivariate case, the causal or error correction model can be written as follows Equation (5):

$\Delta \mathrm{y}_{\mathrm{t}}=\alpha_{0}+\delta \mathrm{e}_{\mathrm{t}-1}+\sum_{\mathrm{m}=1}^{\mathrm{M}} \alpha_{\mathrm{m}} \Delta \mathrm{y}_{\mathrm{t}-\mathrm{m}}+\sum_{\mathrm{n}-1}^{\mathrm{N}} \beta_{\mathrm{n}} \mathrm{x}_{\mathrm{t}-\mathrm{n}}+\varepsilon_{\mathrm{t}}$

where, $y_{t}$ is the dependent variable, $x_{t}$ is the independent variable and $\mathrm{e}_{\mathrm{t}-1}$ is an Error-Correction Term (ECT). According to Granger (1988) and Miller and Russek (1990), there are two potential sources of causation of $y_{t}$ by $x_{t}$ in the error correction model similar to Equation 5, either through $\beta_{\mathrm{n}}$ or through the ECT (i.e., whether or not $\delta=0$ ). In contrast to the standard Granger causality test, model (3) allows for the detection of a Granger causal relation from $\mathrm{x}_{\mathrm{t}}$ to $\mathrm{y}_{\mathrm{t}}$, even if the coefficients on lagged difference terms $\beta_{\mathrm{n}}$ in $\mathrm{y}_{\mathrm{t}}$ are not jointly significant. Thus, the ECT measures the long run causal relationship while $\beta_{\mathrm{n}}$ determine the short run causal relation. Granger (1988), further, notes that cointegration between two or more variables is sufficient to indicate the presence of causality at least in one direction.

The sign and the magnitude of the coefficient of the Error Correction Term (ECT) helps in figuring out the short-term adjustment process. If the value of the coefficient falls between-1 and 0, the ECT tends to cause the dependent variable to converge monotically to its long run equilibrium track in relation to variations in the exogeneous "forcing variables". The greater the magnitude of the coefficient of the error term the greater the response (speed of adjustment) of the dependent variable to the corresponding error correction term .A positive value of the coefficients of the ECT, or a value smaller than-2, will cause dependent variable to diverge. If the value is between- 1 and-2, then the ECT will 
produce dampened fluctuations in the dependent variable about its equilibrium route (Alam and Quazi, 2003).

\subsection{Data Source and Description}

The data used in this study are monthly national average prices of seven selected fruits namely bananas, (Durian = Durio zibethinus L, Guava = Averrhoa carambola, Jackfruit = Artocarpus heterophyllus), papaya, star fruit and water melon. Banana, guava, papaya, star fruit and water melon are the non-seasonal fruits while jackfruit (or cempedak) and durian are seasonal fruits. Durians account the highest in terms of area (accounted for $37.5 \%$ in 2009), followed by bananas (10\%). Each of Jackfruit and water melons accounted for $4 \%$ of the planted area under fruits while durian, guava and star fruit accounted for $1 \%$ each (MAABI, 2009). The selected fruits are exportable items, in particular, watermelons and bananas whose exports were valued at RM 45mn RM20mn, respectively, in 2008. In terms of fruits consumption per capita, the seven fruits accounted for $42 \%$ of the total per capita fruits consumption in the country in 2010 estimated at 63 $\mathrm{kg} /$ person/year. Bananas consumption of 10.9 $\mathrm{kg} /$ person/year is the highest among all fruits $(17 \%)$. It is followed by watermelon and durian ( $9 \%$ each).

The sample periods chosen for this study extend from the January 2000 to December 2010. All price variables are nominal and are adjusted for seasonality. The data is provided by FAMA online databases. Prices are in $\mathrm{RM} / \mathrm{kg}$. It is common to use logarithms when analysing cointegrating relationships between variables, because otherwise, with trending data, the relative error might decline through time and this is inappropriate (Dawson and Tiffin, 2000). Therefore, the data has been transformed into natural logarithms

\section{RESULTS AND DISCUSSION}

\subsection{Unit Root Tests}

Table 1 shows the results of ADF unit root test for the underlying price series in levels and first differences with and without trend. The null hypothesis of existence of unit root cannot be rejected for each of the variables in the level and thus, it is concluded that all the series are non stationary with the presence of unit root. However, the null hypothesis is rejected at the $1 \%$ level or of significance for all of them in their first differences. This indicates that stationarity is achieved for them after the first differencing i.e., all series are I(1).

\subsection{Cointegration Tests}

Using Johansen's maximum likelihood approach, we test the bivariate relationship between farm and retail prices for all fruits under study. The trace and Max-eigen value statistics for testing the rank of cointegration is shown in Table 2.

The results of both tests deny the absence of cointegrating relation between farm and retail prices series for each of the seven fruit types. Furthermore, both tests suggest the presence of at least one cointegrating equation at $5 \%$ or better levels. Cointegration among the nonstationary farm and retail prices means that a linear combination of them is stationary and, consequently, prices tend to move towards this equilibrium relationship in the long run.

\subsection{Causality Tests}

Granger causality tests give further emphasis to the presence of at least unidirectional causality linkages as an indication of some degree of integration. Feedback implies that each market uses information from the other when forming its own price expectations, while unidirectional causality inform about leader- follower relationships in terms of price adjustments

The results of Granger causality test are presented in Table 3. On basis of those results, this study detects long run and short run bidirectional causality from farm price to retail price and vice versa for banana and watermelon i.e., there is feedback between the retail and farm levels of those markets, which means that each market level utilizes information from the other to develop its own price expectations. The prices of jackfruits and durian turned out to be set at the farm level market and transmitted up to the retailers in the long run, as indicated by the ECT negative value and statistical significance. Conversely, they deny the existence of a similar relation in the opposite direction, in the short as well as in the long run and in the same direction, in the short run. Likewise, the results for guava, star fruit and papaya suggest a presence of long run as well as short run unidirectional causality from their farm price to retail prices. However, they reject the presence of causality relation from farm to retail price in the short run as well as in the long run; thus, the prices of guava star fruit and papaya are also set in the farm level.

The symbols " $\stackrel{\mathrm{LR}}{\longrightarrow}$ " and “ $\stackrel{\mathrm{SR}}{\longrightarrow}$ " represent unidirectional causality in the long run and the short run, respectively. 
F. Mohamed Arshad and A.A. Abdel Hameed / American Journal of Applied Sciences 11 (3): 347-355, 2014

Table 1. Results of ADF unit root test for farm and retail prices

\begin{tabular}{|c|c|c|c|c|c|c|}
\hline Fruit & Variable & $\begin{array}{l}\text { Level } \\
\text { Without trend }\end{array}$ & With trend & $\begin{array}{l}1^{\text {st }} \text { difference } \\
\text { Without trend }\end{array}$ & With trend & $\begin{array}{l}\text { Lag } \\
\text { Length }\end{array}$ \\
\hline \multirow[t]{2}{*}{ Banana } & $\operatorname{lnFP} \mathrm{B}_{\mathrm{B}}$ & -0.2017 & -2.3245 & $-12.551 *$ & $-7.4138^{*}$ & 1 \\
\hline & $\operatorname{lnR} P_{B}$ & -0.2754 & -2.5773 & $-11.3586^{*}$ & $-6.6932 *$ & 1 \\
\hline \multirow[t]{2}{*}{ Durian } & $\operatorname{lnFP} P_{D R}$ & -2.2404 & -2.9575 & $-6.07533^{*}$ & $-4.2813^{*}$ & 7 \\
\hline & $\operatorname{lnRP} P_{D R}$ & -2.5136 & -2.7610 & $-5.5941 *$ & $-4.5804 *$ & 4 \\
\hline \multirow[t]{2}{*}{ Guava } & $\operatorname{lnFP}_{\mathrm{G}}$ & 0.1708 & -1.5197 & $-6.5478^{*}$ & $-6.7586^{*}$ & 4 \\
\hline & $\operatorname{lnRP} P_{G}$ & -0.6771 & -0.8679 & $-12.1885^{*}$ & $-12.152 *$ & 4 \\
\hline \multirow[t]{2}{*}{ Jackfruits } & $\operatorname{lnFP}{ }_{J}$ & -2.2642 & -2.9870 & $-5.1621 *$ & $-5.1551 *$ & 5 \\
\hline & $\operatorname{lnRP} P_{J}$ & -2.1557 & -2.7771 & $-5.1527 *$ & $-4.9871 *$ & 6 \\
\hline \multirow[t]{2}{*}{ Papaya } & $\operatorname{lnFP} P_{P}$ & -0.6824 & -2.0128 & $-8.8020 *$ & $-8.1937 *$ & 1 \\
\hline & $\operatorname{lnRP} P_{P}$ & 1.2345 & -1.4276 & $-14.4519 *$ & $-14.768 *$ & 2 \\
\hline \multirow[t]{2}{*}{ Star Fruit } & $\operatorname{lnFP}_{\mathrm{S}}$ & -1.7687 & -2.4030 & $-6.8103^{*}$ & $-6.7140 *$ & 2 \\
\hline & $\operatorname{lnRP}_{S}$ & -1.5977 & -2.4883 & $-6.3651 *$ & $-6.4915^{*}$ & 4 \\
\hline \multirow[t]{2}{*}{ Water Melon } & $\operatorname{lnFP}_{\mathrm{W}}$ & -2.0363 & -2.2414 & $-6.9745^{*}$ & $-5.5032 *$ & 4 \\
\hline & $\operatorname{lnRP}_{\mathrm{W}}$ & -2.4896 & -2.5267 & $-5.2993 *$ & $-5.2597 *$ & 4 \\
\hline
\end{tabular}

Note: $*$ denote $5 \%$ significance level.

Table 2. Johansen cointegration tests results

\begin{tabular}{|c|c|c|c|c|}
\hline Fruits & Test statistics & $\begin{array}{l}\mathrm{H}_{0} \text { : No cointegrating } \\
\text { relation }\end{array}$ & $\begin{array}{l}\mathrm{H}_{0} \text { : At most one } \\
\text { cointegrating relation }\end{array}$ & $\begin{array}{l}\text { Cointegration } \\
\text { rank }\end{array}$ \\
\hline \multirow[t]{2}{*}{ Bananas (2) } & Trace & $\begin{array}{l}17.3426^{*} \\
{[0.0067]}\end{array}$ & $\begin{array}{l}4.4314 * \\
{[0.0419]}\end{array}$ & 2 \\
\hline & $\lambda_{\xi \alpha \mu}$ & $\begin{array}{l}12.91121 * \\
{[0.0250]}\end{array}$ & $\begin{array}{l}4.4314 * \\
{[0.0419]}\end{array}$ & \\
\hline \multirow[t]{2}{*}{ Durians (2) } & Trace & $\begin{array}{l}22.75386^{*} \\
{[0.0034]}\end{array}$ & $\begin{array}{l}1.557921 \\
{[0.2120]}\end{array}$ & 1 \\
\hline & $\lambda_{\xi \alpha \mu}$ & $\begin{array}{l}21.19594 * \\
{[0.0034]}\end{array}$ & $\begin{array}{l}1.557921 \\
{[0.2120]}\end{array}$ & \\
\hline \multirow[t]{2}{*}{ Guava (2) } & Trace & $\begin{array}{l}27.8008^{*} \\
{[0.0004]}\end{array}$ & $\begin{array}{l}0.1078 \\
{[0.7427]}\end{array}$ & 1 \\
\hline & $\lambda_{\xi \alpha \mu}$ & $\begin{array}{l}27.6923^{*} \\
{[0.0002]}\end{array}$ & $\begin{array}{l}0.1078 \\
{[0.7427]}\end{array}$ & \\
\hline \multirow[t]{2}{*}{ Jackfruits (1) } & Trace & $\begin{array}{l}21.09352 * \\
{[0.0064]}\end{array}$ & $\begin{array}{l}0.156727 \\
{[0.6922]}\end{array}$ & 1 \\
\hline & $\lambda_{\xi \alpha \mu}$ & $\begin{array}{l}20.93679 * \\
{[0.0038]}\end{array}$ & $\begin{array}{l}0.156727 \\
{[0.6922]}\end{array}$ & \\
\hline \multirow[t]{2}{*}{ Papaya (2) } & Trace & $\begin{array}{l}20.3419^{*} \\
{[0.0086]}\end{array}$ & $\begin{array}{l}1.772 \\
{[0.1831]}\end{array}$ & 1 \\
\hline & $\lambda_{\xi \alpha \mu}$ & $\begin{array}{l}18.5698 * \\
{[0.0098]}\end{array}$ & $\begin{array}{l}1.772 \\
{[0.1831]}\end{array}$ & \\
\hline \multirow[t]{2}{*}{ Star Fruit (4) } & Trace & $\begin{array}{l}16.5322^{*} \\
{[0.0348]}\end{array}$ & $\begin{array}{l}3.0956 \\
{[0.0785]}\end{array}$ & 1 \\
\hline & $\lambda_{\xi \alpha \mu}$ & $\begin{array}{l}15.4366^{*} \\
{[0.0373]}\end{array}$ & $\begin{array}{l}3.0956 \\
{[0.0785]}\end{array}$ & \\
\hline \multirow[t]{2}{*}{ Water Melons (1) } & Trace & $\begin{array}{l}42.13 * \\
{[0.0001]}\end{array}$ & $\begin{array}{l}19.7238^{*} \\
{[0.0001]}\end{array}$ & 2 \\
\hline & $\lambda_{\xi \alpha \mu}$ & $\begin{array}{l}22.4062 * \\
{[0.0021]}\end{array}$ & $\begin{array}{l}19.7238^{*} \\
{[0.0001]}\end{array}$ & \\
\hline
\end{tabular}

Notes: Numbers in square brackets give the asymptotic significance level (p values) estimated in MacKinnon et al. (1999), numbers in parentheses are the lag intervals, * denotes rejection of the hypothesis at the $5 \%$ level. 
Table 3. F-statistics for tests of granger causality

\begin{tabular}{|c|c|c|c|c|c|}
\hline \multirow{2}{*}{$\begin{array}{l}\text { Fruit type } \\
\text { (F-statistics) }\end{array}$} & \multirow[b]{2}{*}{ Dependent variables } & \multicolumn{2}{|c|}{ Independent variables } & \multirow{2}{*}{$\begin{array}{l}\text { Coefficients } \\
\text { of ECT }\end{array}$} & \multirow[b]{2}{*}{ Causal reference } \\
\hline & & $\Delta \operatorname{lnR} P_{i}$ & $\Delta \operatorname{lnFP} P_{i}$ & & \\
\hline \multirow[t]{4}{*}{ Bananas } & \multirow[t]{2}{*}{$\Delta \ln R P_{\mathrm{B}}$} & - & $3.02997 *$ & $-0.83503^{*}$ & $\mathrm{FP}_{\mathrm{B}} \stackrel{L R}{\longrightarrow} \mathrm{RP}_{\mathrm{B}}$ \\
\hline & & - & {$[0.0365]$} & $(-3.59193)$ & $\mathrm{FP}_{\mathrm{B}} \stackrel{S R}{\longrightarrow} \mathrm{RP}_{\mathrm{B}}$ \\
\hline & \multirow[t]{2}{*}{$\Delta \operatorname{lnFP} P_{B}$} & $4.288747 *$ & - & $-0.241329 *$ & $\mathrm{RP}_{\mathrm{B}} \stackrel{L R}{\longrightarrow} \mathrm{FP}_{\mathrm{B}}$ \\
\hline & & {$[0.0065]$} & - & $(-3.13012)$ & $\mathrm{RP}_{\mathrm{B}} \stackrel{S R}{\longrightarrow} \mathrm{FP}_{\mathrm{B}}$ \\
\hline \multirow[t]{4}{*}{ Durians } & \multirow[t]{2}{*}{$\Delta \operatorname{lnR} P_{D R}$} & - & 0.65048 & -0.54222 & $\mathrm{FP}_{\mathrm{DR}} \stackrel{L R}{\longrightarrow} \mathrm{RP}_{\mathrm{DR}}$ \\
\hline & & - & [0.78549] & $(-3.31304)$ & $\mathrm{FP}_{\mathrm{DR}} \not \stackrel{s}{\longrightarrow} \mathrm{FP}_{\mathrm{DR}}$ \\
\hline & \multirow[t]{2}{*}{$\Delta \operatorname{lnFP} P_{D R}$} & 0.14103 & - & -0.03641 & $\mathrm{RP}_{\mathrm{DR}} \not \not R \rightarrow \mathrm{FP}_{\mathrm{DR}}$ \\
\hline & & [0.550477] & - & $(-0.35338)$ & $\mathrm{RP}_{\mathrm{DR}} \not \stackrel{s}{\longrightarrow} \mathrm{FP}_{\mathrm{DR}}$ \\
\hline \multirow[t]{4}{*}{ Guava } & \multirow[t]{2}{*}{$\Delta \operatorname{lnRP} P_{G}$} & - & $5.75729 *$ & $-0.487114 *$ & $\mathrm{FP}_{\mathrm{G}} \stackrel{L R}{\longrightarrow} \mathrm{RP}_{\mathrm{G}}$ \\
\hline & & - & {$[0.0041]$} & $(-3.89605)$ & $\mathrm{FP}_{\mathrm{G}} \stackrel{S R}{\longrightarrow} \mathrm{RP}_{\mathrm{G}}$ \\
\hline & \multirow[t]{2}{*}{$\Delta \operatorname{lnFP}_{\mathrm{G}}$} & 0.65418 & - & 0.073157 & $\mathrm{RP}_{\mathrm{G}} \stackrel{2 R}{\longrightarrow} \mathrm{FP}_{\mathrm{G}}$ \\
\hline & & [0.5217] & - & -1.03945 & $\mathrm{RP}_{\mathrm{G}} \not \stackrel{s R}{\longrightarrow} \mathrm{FP}_{\mathrm{G}}$ \\
\hline \multirow[t]{4}{*}{ Jackfruits } & \multirow[t]{2}{*}{$\Delta \operatorname{lnRP} P_{J}$} & - & 2.497175 & $-0.515360 *$ & $\mathrm{FP}_{\mathrm{J}} \stackrel{L R}{\longrightarrow} \mathrm{RP}_{\mathrm{J}}$ \\
\hline & & - & [0.08653] & $(-3.66522)$ & $\mathrm{FP}_{\mathrm{J}} \not \mathrm{RP}_{\mathrm{J}}$ \\
\hline & \multirow[t]{2}{*}{$\Delta \operatorname{lnFP}_{\mathrm{J}}$} & 2.23074 & - & -0.03816 & $\mathrm{RP}_{\mathrm{J}} \nrightarrow \mathrm{FP}_{\mathrm{J}}$ \\
\hline & & {$[0.0857]$} & - & $(-0.53224)$ & $\mathrm{RP}_{\mathrm{J}} \not \stackrel{S R}{\longrightarrow} \mathrm{FP}_{\mathrm{J}}$ \\
\hline \multirow[t]{4}{*}{ Papaya } & \multirow[t]{2}{*}{$\Delta \ln R P_{P}$} & - & 7.913105 & $-0.417294^{*}$ & $\mathrm{FP}_{\mathrm{P}} \stackrel{L R}{\longrightarrow} \mathrm{RP}_{\mathrm{P}}$ \\
\hline & & - & {$[0.0006]$} & $(-3.28935)$ & $\mathrm{FP}_{\mathrm{P}} \stackrel{S R}{\longrightarrow} \mathrm{RP}_{\mathrm{P}}$ \\
\hline & \multirow[t]{2}{*}{$\Delta \operatorname{lnFP}_{\mathrm{P}}$} & 0.16705 & - & 0.20562 & $\mathrm{RP}_{\mathrm{P}} \stackrel{L R}{\longrightarrow}{ }_{\mathrm{FP}_{\mathrm{P}}}$ \\
\hline & & [0.8463] & - & -1.00079 & $\mathrm{RP}_{\mathrm{P}} \not \stackrel{S R}{\longrightarrow} \mathrm{FP}_{\mathrm{P}}$ \\
\hline \multirow[t]{4}{*}{ Star fruit } & \multirow[t]{2}{*}{$\Delta \ln R P_{S}$} & - & $2.85988^{*}$ & $-0.466285^{*}$ & $\mathrm{FP}_{\mathrm{S}} \stackrel{L R}{\longrightarrow} \mathrm{RP}_{\mathrm{S}}$ \\
\hline & & - & {$[0.0451]$} & $(-3.44982)$ & $\mathrm{FP}_{\mathrm{S}} \stackrel{S R}{\longrightarrow} \mathrm{RP}_{\mathrm{S}}$ \\
\hline & $\Delta \operatorname{lnFP}_{\mathrm{S}}$ & 0.14103 & - & 0.7227 & $\mathrm{RP}_{\mathrm{S}} \nrightarrow \stackrel{I R}{\longrightarrow} \mathrm{FP}_{\mathrm{S}}$ \\
\hline & & {$[0.55047]$} & - & -0.6943 & $\mathrm{RP}_{\mathrm{S}} \not \stackrel{S R}{\longrightarrow} \mathrm{FP}_{\mathrm{G}}$ \\
\hline \multirow[t]{3}{*}{ Watermelons } & \multirow[t]{2}{*}{$\Delta \operatorname{lnR} P_{w}$} & - & $2.92535^{*}$ & $-0.29877^{*}$ & $\mathrm{FP}_{\mathrm{W}} \stackrel{L R}{\longrightarrow} \mathrm{RP}_{\mathrm{W}}$ \\
\hline & & - & [0.04321] & $(-2.96977)$ & $\stackrel{S R}{\longrightarrow} \mathrm{RP}_{\mathrm{w}}$ \\
\hline & \multirow[t]{2}{*}{$\Delta \operatorname{lnFP} P_{w}$} & $3.63585^{*}$ & - & $-0.173796^{*}$ & $\mathrm{RP}_{\mathrm{W}} \stackrel{L R}{\longrightarrow} \mathrm{FP}_{\mathrm{W}}$ \\
\hline$S R$ & & {$[0.0292]$} & - & $(-3.24097)$ & $\mathrm{RP}_{\mathrm{W}} \stackrel{S R}{\longrightarrow} \mathrm{FP}_{\mathrm{W}}$ \\
\hline
\end{tabular}

Note: Numbers in parentheses are t- statistics, numbers in square brackets are $\mathrm{p}$ values and $*$ denotes significance at $5 \%$ level or better.

The symbols " $\not R R \rightarrow$, and " $\not s R \rightarrow$ "denote absence of causality in the long run and the short run, respectively.

Additionally, this study finds that the coefficients of the ECT in all the models with $\triangle \mathrm{LnRPi}$ as dependant variables carry a negative sign. This suggests that the ECT acts as a force that causes the integrated variables to return to their long run relation when they deviate from it. Furthermore, the magnitude of the error correction term indicates that it tends to correct the deviation at low to high speeds. With regard to the causality results, the following points merit emphasis. First, the inclusion of an error correction term in these causal models ensures a proper test of the existence or absence of a material relationship between farm and retail fruit prices in Malaysia. Second, the error correction term not only measures disequilibrium, but also captures deviations from it. The values of the ECT for banana and 
watermelon models indicate that although there is a bidirectional causality between farm and retail prices of these fruits, yet the retail prices adjust to the shocks in the farm prices at faster rate. In other words, the response of retailers to the price shock at farm level is faster than the response of farmers to the changes in retail prices, which is a plausible result.

\section{CONCLUSION}

This study investigates the market linkages for retail prices and the farm-gate price for selected fruits in Malaysia in the period January 2000 through December 2010. Cointegration tests are applied to study long run relationships and Granger causality tests are used to obtain the general pattern of influences of price shocks at farm and retail market levels for fruits under study. The results provide empirical evidence about cointegration between the price series. These findings lend support to hypothesis that there is a long run relationship between the two price levels series for all the fruits under study. Further, Granger causality tests indicate a unidirectional relationship from producer prices to retail prices with no evidence of the reverse causality feedback for each of jackfruits, durian. This result supports the notion that retailers do adjust to shocks in producer prices, while the effects of retail market shocks are largely confined to retail markets. These findings are in accordance with most empirical studies carried out on agricultural markets (Cramon-Taubadel, 1998; Bojnec and Gunther, 2005; Bakucs and Ferto, 2006). The results are plausible as the two fruits are seasonal in nature and their production is highly unpredictable and unstable as they are highly susceptible to weather changes. The supply is highly inelastic due to long gestation period which explains the unidirectional price responses. The findings for banana and watermelons reveal that there is long run bidirectional causality from farm market level to retail markets and vice versa, which indicate that there is feedback between the retail and farm levels of those markets. This means that each market level utilizes information from the other to develop its own price expectations. In particular, the highly significant bidirectional causality between market levels of banana in the long run as well as in the short run, reveals the high degree of integration and efficiency of the markets of these two fruits. Unlike the earlier seasonal fruits, bananas and watermelons available all year round and the level of commercialisation is a little higher that jackfruits and durian. The supply is relatively elastic compared to the earlier two fruits as bananas and watermelons can be produced all year around. Under such market characteristics, the farm and retail prices are responsive to each other which explain the bidirectional relationship between them in the long term. Future empirical work in this area should strive for a more detailed analysis to investigate for price transmission asymmetry (segmented price symmetry).

\subsection{End Note}

The authors acknowledge and thank the financial support of the Federal Agricultural Marketing Authority to this study.

\section{REFERENCES}

Alam, I. and R. Quazi, 2003. Determinants of capital flight: An econometric case study of Bangladesh. Int. Rev. Applied Econ., 17: 85-103. DOI: 10.1080/713673164

Arshad, F.M, A. Radam and Z. Mohamed, 2005a. The fruits industry in Malaysia, issues and challenges. Universiti Putra Malaysia Press, Serdan.

Arshad, F.M., A. Radam and Z. Mohamed, 2005b. The Fruits Industry in Malaysia: Issues and Challenges. 1st Edn., Universiti Putra Malaysia Press, Serdang, ISBN-10: 9832871794, pp: 102.

Bakucs, L.Z. and I. Ferto, 2006. Marketing margins and price transmission on the Hungarian beef market. Food Econ. Acta Agric. Scand C, 3: 151-160. DOI: 10.1080/16507540601176075

Bojnec, S. and P. Gunther, 2005. Vertical market integration and competition: The meat sector in Slovenia. Agric. Food Sci., 14: 236-249. DOI: 10.2137/145960605775013182

Colclough, W.G. and M.D. Lange, 1982. Empirical evidence of causality from consumer to wholesale prices. J. Econ., 19: 379-384. DOI: 10.1016/03044076(82)90012-4

Cramon-Taubadel, S.V., 1998. Estimating asymmetric price transmission with the error correction representation: An application to the German pork market. Eur. Rev. Agric. Econ., 25: 1-18. DOI: 10.1093/erae/25.1.1

Dawson, P.J. and R. Tiffin, 2000. SStructural breaks, cointegration and the farm-retail price spread for lamb. Applied Econ., 32: 1281-1286. DOI: 10.1080/000368400404434

Dickey, D.A. and W.A. Fuller, 1981. Likelihood ratio statistics for autoregressive time series with a unit root. Econometrica, 49: 1057-1072. 
Enders, W. and P.L. Siklos, 1998. The term structure: Testing for an equilibrium with asymmetric adjustment. Iowa State University Working Paper, Mimeo.

Engle, R.F. and C.W. Granger, 1987. Co-integration and error correction: Representation, estimation and testing. Econometrica, 55: 251-276.

Geweke, J., R. Meese and W. Dent, 1983. Comparing alternative tests of causality in temporal systems is: Analytic results and experimental evidence. J. Economet., 21: 161-94. DOI: 10.1016/03044076(83)90012-X

Goodwin B.K. and D.C. Harper, 2000. Price Transmission, threshold behaviour and asymmetric adjustment in the US pork sector. J. Agric. Applied Econ., 32: 543-553.

Goodwin, B.K. and M.T. Holt, 1999. Price Transmission and Asymmetric Adjustment in the U.S. Beef Sector. Am. J. Agric. Econ., 81: 630-637. DOI: $10.2307 / 1244026$

Goodwin, B.K., T.J. Grennes and C. McCurdy, 1996. Spatial price dynamics and integration in Russian food markets, North Caroline State University, Mimeo.

Granger, C.W.J., 1969. Investigating causal relations by econometric models and cross-spectral methods, Econometrica, 37: 424-438.

Granger, C.W.J., 1980. Testing for causality. J. Econ. Dynamics Control, 4: 229-252.

Granger, C.W.J., 1988. Some recent development in a concept of causality. J. Economet., 39: 199-221. DOI: 10.1016/0304-4076(88)90045-0

Guilkey, D.K. and M.K. Salemi, 1982. Small sample properties of three tests for granger-causal ordering in a bivariate stochastic system. Rev. Econ. Stat., 64: 668-680.
Johansen, S. and K. Juselius, 1990. Maximum likelihood estimation and inference on cointegration--with applications to the demand for money. Oxford Bull. Econ. Stat., 52: 169-210. DOI: 10.1111/j.14680084.1990.mp52002003.X

Johansen, S., 1988. Statistical analysis of cointegration vectors. J. Econ. Dynamics Control, 12: 231-254. DOI: 10.1016/0165-1889(88)90041-3

Johansen, S., 1991. Estimation and hypothesis testing of cointegration vectors in gaussian vector autoregressive models. Econometrica, 59: 15511580.

MAABI, 2009. Agriculture Statistical Handbook 2008. Ministry of Agriculture and Agro-based Industries, Putrajaya.

Mackinnon, J.G., A.A. Haug and L. Michelis, 1999. Numerical distribution functions of likelihood ratio tests for cointegration. J. Applied Economet., 14: 563-577. DOI: $10.1002 /($ SICI)10991255(199909/10)14:5<563::AIDJAE530>3.0.CO;2-R

Miller, S. and F.S. Russek, 1990. Co-integration and error-correction models: The temporal causality between government taxes and spending. Southern Econ. J., 57: 221-229.

Palaskas, T.B., 1995. Statistical analysis of price transmission in the European Union. J. Agric. Econ., 46: 60-69. DOI: $10.1111 /$ j.14779552.1995.tb00752.x

Romilly, P., H. Song and X. Liu, 2001. Car ownership and use in Britain: A comparison of the empirical results of alternative cointegration estimation methods and forecasts. Applied Econ., 33: 18031818. DOI: $10.1080 / 00036840011021708$ 